\title{
INTENSIFICATION OF ANTIVIRAL THERAPY OF CHRONIC HEPATITIS B BY MEANS OF INTRADERMAL IMMUNIZATION WITH AUTOLEUKOCYTES
}

10.36740/WLek202010109

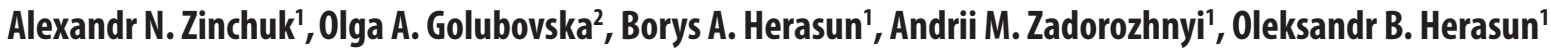 \\ 'DANYLO HALYTSKY LVIV NATIONAL MEDICAL UNIVERSITY, LVIV, UKRAINE \\ 2BOGOMOLETS NATIONAL MEDICAL UNIVERSITY, KYIV, UKRAINE
}

\begin{abstract}
The aim: Was a trial of intradermal immunization with native autoleukocytes as a curative vaccine.

Materials and methods: Thus, 3-shot series vaccination by means of intradermal injection of autoleukocytes with $30-40$ days interval was conducted for patients who, in spite of continuous (at least 2 years) therapy with nucleotide analogue, experienced HBV DNA reproduction. For this procedure, $80-100$ ml of a patient's heparinized venous blood was being precipitated at the temperature $37^{\circ} \mathrm{C}$ for $120-140$ minutes, after blood plasma was being centrifuged at $450 \mathrm{~g}$ for 8 minutes. The precipitate was resuspended in $1-1.5 \mathrm{ml}$ of blood serum and injected intradermally in the region of the back.

Results: Viral load decreased in all patients even after single immunization; it was possible to achieve a negative result by ultrasensitive PCR method in $23.33 \%$ of patients in the group of patients who did not respond adequately to antiviral therapy.

Conclusions: In patients with chronic hepatitis B, intradermal immunization with autoleukocytes has a significant impact on intensity of virus replication. It is confirmed by a considerable reduction of DNA HBV amount in patients, in whom antiviral therapy was stopped before immunization
\end{abstract}

KEY WORDS: chronic hepatitis B, therapy with nucleotide analogue, autoleukocyte vaccination

Wiad Lek. 2020;73(10):2156-2159

\section{INTRODUCTION}

It is known that the complexity of chronic hepatitis B treatment is caused by various possibilities of hepatitis $B$ virus (HBV) to avoid the immune response and antiviral therapy. Ability of $\mathrm{HBV}$ to mutate and especially integration of DNA HBV in hepatocyte genome enables the virus to survive even in conditions of antiviral therapy [1-3].

Attempts to use different curative vaccines have been made due to insufficient efficacy of antiviral therapy for a prolonged time. However, negative influence of the virus on immune cells, enormous excessive HBsAg synthesis and different HBV mutations make them less efficient.

Thus, the aim of our research was a trial of intradermal immunization with native autoleukocytes as a curative vaccine. It is known that autoleukocyte immunization is usually used for the treatment of different autoimmune processes [4], particularly the ones regarded as extracellular signs of viral hepatitis [5-7]. Besides, autoleukocytes may be used as a virus-containing material in certain viral infections. Thus, intradermal immunization with autoleukocytes proved to be effective in the treatment of frequently recurrent herpes, caused by 1 and 2 types of herpes virus [8]. Autoleukocyte immunization is also investigated for the treatment of HIV infection [9].

A wide spectrum of autoleukocyte immunization causes investigation of treatment method for patients with chronic hepatitis B. In addition, autolymphocytes may be used as an individual virus-containing material ("personified therapy"), which is especially important for chronic hepatitis $\mathrm{B}$ treatment and distinctly differentiates this method from other curative vaccines.

The aim of the research was to trial autoleukocyte immunization for intensification of antiviral therapy with nucleotide analogue. Tenofovir was selected as a medication of choice in this group.

\section{THE AIM}

The aim was a trial of intradermal immunization with native autoleukocytes as a curative vaccine.

\section{MATERIALS AND METHODS}

\section{PATIENTS}

Totally, 30 patients with chronic hepatitis B, aged 22-63 years (18 women and 12 men), were immunized; they did not have liver cirrhosis, other viral hepatitis and HIV-infection. The investigation included those in whom, despite of continuous therapy with tenofovir (at least 2 years), DNA HBV replication continued. In such patients after achievement of maximal individual effect of antiviral ther- 
Table 1. Influence of autoleukocyte immunization on DNA HBV intensity

\begin{tabular}{cccccc}
\hline \multirow{2}{*}{$\begin{array}{c}\text { Amount of HBV DNA before } \\
\text { immunization (IU/mI) }\end{array}$} & $\begin{array}{c}\text { Number } \\
\text { of patients }\end{array}$ & \multicolumn{4}{c}{ Amount after immunization (IU/mI) } \\
\cline { 3 - 6 } from $3 \times 10^{4}$ to $\geq 1 \times 10^{8}$ & 8 & $5^{* *}(62.5 \%)$ & $3(37.5 \%)$ & - & Absence of effect \\
\hline$<2 \times 10^{3}$ & 16 & - & 11 & 5 & - \\
\hline $\begin{array}{c}\text { detected only by } \\
\text { supersensitive PCR method }\end{array}$ & 6 & 4 & 2 & 4 \\
\hline Total & 30 & 5 & 18 & 7 \\
\hline
\end{tabular}

* DNA HBV could be detected only by supersensitive PCR method. (sensitivity $-5 \mathrm{IU} / \mathrm{ml}$ ).

${ }^{*}$ In one case a relapse occurred.

apy, reduction of viral load further ceased: considerable changes in the level of viral load were not observed at least during 8-month monitoring. For further intensification of efficacy of antiviral therapy, patients were immunized with native autoleukocytes. Immunization was conducted three times with 30-40-day interval, in some cases many times.

The patients were divided into 3 groups, depending on viral load.

In the first group of 8 patients $(26.67 \%$ from total number), DNA HBV amount during immunization with autoleukocytes constituted from $3 \times 10^{4}$ to $\geq 1 \times 10^{8} \mathrm{IU} / \mathrm{ml}$; in 16 patients of the second group (53.33\%) - viral load was less $2 \times 10^{3} \mathrm{IU} / \mathrm{ml}$; in $6(20.0 \%)$ patients of the third group DNA HBV was revealed only by qualitative ultrasensitive PCR method (analytic sensitivity $5 \mathrm{IU} / \mathrm{ml}$ ).

In 26 patients, virus D genotype (86.67\%) was revealed, in $4-\mathrm{A}(13.33 \%)$.

\section{AUTOLEUKOCYTE IMMUNIZATION}

Leukocytes were isolated by means of precipitation of heparinized venous blood. Thus, $80-100 \mathrm{ml}$ of venous blood was put into a bottle with Heparinum natricym (Heparini-Richter) in the ratio 50 units of heparin per $10 \mathrm{ml}$ of blood and precipitated at $\mathrm{t} 37^{\circ} \mathrm{C}$ for $120-140$ minutes. Blood plasma was obtained by centrifuging at $450 \mathrm{~g}$ for 7 minutes. The suspension was resuspended in 1-1.5 ml of own blood serum.

Autoleukocyte immunization of peripheral blood was conducted as follows: leukocytes were injected intradermally (to the formation of "a lemon crust") in the dose 0.1 $\mathrm{ml}$ into 10-15 points in the skin of the back.

The viral load and qualitative determination of $\mathrm{HBsAg}$ was conducted before immunization and in 30-35 days after it. DNA HBV was determined by qualitative or, if needed, quantitative supersensitive PCR method (sensitivity $-5 \mathrm{IU} / \mathrm{ml}$ ).

Test-system "Corbett Research" (Australia) was used for qualitative determination of DNA HBV by PCR method. The investigation by supersensitive PCR method was conducted in the Centre of molecular diagnostics of the Central scientific-research institute of epidemiology of Rospotrebnadzor (Moscow, Russia).

Quantitative determination of HBsAg was conducted by hemiluminescent immunoassay on microparticles (CMIA) with the use of test-system ABBOT Diagnostics (USA).
Hepatitis $\mathrm{C}$ in patients, included in the investigation group, was excluded determining TNA HCV by qualitative PCR method (Real-time), using test-system "Corbett Research" (Australia). Anti- HEV IgM та IgG by ELISA (test-system "Vector Best" (Russia) was used to exclude hepatitis E. Patients were examined for HIV-infection with ELISA by means of test-system of the $4^{\text {th }}$ generation Ultra HIV Ag-Ab (Bio-Rad, France).

To exclude liver cirrhosis, the level of fibrosis was determined by Fibro Test (18 patients) or liver biopsy was performed (12 patients).

\section{RESULTS}

Results of autoleukocyte immunization, conducted during antiviral therapy with nucleotide analogues, are presented in table 1.

Analysis of treatment results in groups of patients.

The first group. A 3-shot series autoleukocyte immunization in the group of eight patients with chronic hepatitis $B$, in which the amount of DNA HBV constituted $\geq 3 \times 10^{4}$ $\mathrm{IU} / \mathrm{ml}$ before immunization and during antiviral therapy, resulted in a significant decrease in the intensity of DNA HBV replication in all patients.

In 5 patients of the first subgroup (62.5\%) after immunization qualitative meaning of DNA HBV amount decreased below $1000 \mathrm{IU} / \mathrm{ml}$ (it ranged within 160-300 IU/ $\mathrm{ml}$ throughout a year of further monitoring in 4 of them); in 3 - determination of HBV DNA became possible only due to supersensitive PCR method. Thus, a positive efficacy of treatment was observed in all patients of the group, however, unfortunately, DNA HBV was further detected (negative result of ultrasensitive PCR method could not be achieved).

In one patient from this subgroup, in spite of a threeyear antiviral therapy with tenofovir, amount of HBV DNA exceeded $1 \times 10^{8} \mathrm{IU} / \mathrm{ml}$. Already in 30 days after the first immunization amount of DNA HBV decreased to $2.1 \times 10^{3} \mathrm{IU} / \mathrm{ml}$, and after the third one it constituted $420 \mathrm{IU} /$ $\mathrm{ml}$. Thus, inhibition of virus replication occurred rapidly and intensively, at the same time HBsAg in blood serum almost did not change. Immunization and treatment of the patient with tenofovir was ceased in order to track further development of immune response, which is now regarded as an incorrect decision, since concentration of HBV DNA 
increased to the previous level: over $1 \times 10^{8} \mathrm{IU} / \mathrm{ml}$, which was seen on examination in 4 months.

Because of recurrence of intensive reproduction of the virus, immunization was repeated again during tenofovir treatment - concentration of virus started to decrease, though significantly slower. Multiple immunization was conducted with a one-month interval and before each of them viral load constituted $4.4 \times 10^{7} \mathrm{IU} / \mathrm{ml}$; after the $6^{\text {th }}$ one $-1.5 \times 10^{4} \mathrm{IU} / \mathrm{ml}$, and after the $7^{\text {th }}-11 \mathrm{IU} / \mathrm{ml}$. The treatment continued.

Thus, the influence of the repeated process of immunization on HBV replication level significantly weakened in comparison with the previous one. It seems that untimely cessation of therapy promoted the development of virus mutation and it resulted in weakening of the efficacy of vaccination.

The second group of patients. Among 16 patients with DNA HBV amount $<2 \times 10^{3} \mathrm{IU} / \mathrm{ml}$, in $11(68.75 \%)$ of them viral load was only detected by ultrasensitive PCR method after 3-shot series immunization with autoleukocytes; and in 5 patients (31.25\%) DNA HBV was not detected anymore throughout a year (period of monitoring).

The third group of patients. Among 6 patients, in whom after continuous therapy HBV DNA could be revealed only by supersensitive PCR method, in 2 of them the virus was not detected anymore after 3 -shot series immunization (33.33\%). Other patients additionally had 3-4 immunizations during antiviral therapy for cessation of virus replication, but the result of ultrasensitive PCR method remained positive.

Cessation of HBsAg synthesis occurred in 6 patients from 7 , in this case a negative result of ultrasensitive PCR method could be achieved (85.71\%). In other patients, despite a considerable decrease in viral load, HBsAg amount decreased moderately.

Thus, autoleukocyte immunization during antiviral therapy intensifies efficacy of treatment: viral load significantly decreases, though the level of treatment has an individual character. However, HBV DNA replication could be stopped, according to data of ultrasensitive PCR method, only in seven patients from $30(23.33 \%)$.

For a year (period of monitoring), the achieved results remained however during antiviral therapy with nucleotide analogue.

\section{DISCUSSION}

It is obvious that treatment efficacy requires further monitoring; duration of antiviral therapy has to be studied.

Mechanism of action of intradermal immunization with noninactivated autoleukocytes has been studied incompletely; however, it may be regarded as a complex influence of autoreactive cells on immune reaction mechanisms.

Influence of autoleukocyte immunization on the condition of autoimmune processes is explained by the presence of transmission factor in lymphocytes, which makes such immunization similar to vaccination for prevention of infectious diseases [4]. However, lymphocytes, where
HBV replication occurs, are simultaneously a natural "virus-containing material" [8].

In case of intradermal injection, autoreactive cells may cause the condition of activity of cell lymphocyte-mediated immune reaction by regeneration of cytotoxic leukocytes.

The process of correction of Erne network - idiotype-anti-idiotype regulation of immune reaction, activation of CD3+, CD8+, CD25+-lymphocytes, also CD3+, CD8+, CD28+-lymphocytes occurs simultaneously with blockage of Fc-receptors, as well as glycoprotein, lectin receptors on B-lymphocytes are also important $[4,6]$.

Thus, immunization with virus-containing lymphocytes not only intensifies antiviral immunity [8], but at the same time decreases synthesis of cryoglobulins [10] and influences other autoimmune processes [5-7], which, theoretically, may also have a positive impact on efficacy of antiviral therapy.

Isolation of lymphocytes by means of prior precipitation of blood leads to penetration of erythrocytes into leukocyte mass. In this case, in our opinion, they can be compared to adjuvants, which are added to vaccines for intensification of their efficacy by delaying "removal" of antigen, moreover, it is known that virus and its certain antigens are present in erythrocytes of patients with chronic hepatitis B.

According to our data, obtained in investigations in vitro, autoleukocyte immunization intensifies cell's antiviral immunity. It is confirmed by the fact that in the culture of leukocytes, produced from the cells that are obtained from a patient's peripheral blood in 10-12 days after immunization, sensitivity to HBsAg becomes much more intensive than in the culture of the cells produced before [11].

Whether genotype of virus influences the efficacy of immunization could not be established, which is caused by a small number of patients with A genotype of virus.

\section{CONCLUSIONS}

In patients with chronic hepatitis B, intradermal immunization with autoleukocytes has a significant impact on intensity of virus replication. It is confirmed by a considerable reduction of DNA HBV amount in patients, in whom antiviral therapy was stopped before immunization (after achievement of certain individual level).

It is especially seen in patients with high viral load. However, administration of autoleukocyte immunization as a curative vaccine for chronic hepatitis $B$ requires further study and improvement; duration of treatment with this antiviral medicine has not been established yet.

\section{REFERENCES}

1. Ganem D., Prince A.M. Hepatitis B virus infection - natural history and clinical consequences. N. Engl. J. Med. 2004; 11:1118-1129.

2. Brechot C. Pathogenesis of hepatitis B virus-related hepatocellular carcinoma: old and new paradigms. Gastroenterology. 2004; 5:56-61.

3. Luo K., Hou J., Wang Z. et al. Prevalence of naturally occurring surface gene variants of hepatic $B$ virus in nonimmunized surface antigen negative Chinese carriers. Hepatology. 2001; 5:1027-1034.

4. Golab J., Jakobisiak M., LasekW., Stoklosa T. Immunologia. Wydawnictwo Naukowe PWN. 2007. 
5. Gerasun B.A., Andreychyn M.A., Hrytsko R.Y. et al. Use of leukocytes in cell therapy. Gepatologia. 2012;16 (2): 4-17.

6. Holubovska 0.A., Shkurba A.V., Herasun 0.B., Vorozhbyt 0.V. et al. Intradermal Autoleukocyte Immunization - Personified Method of Cell Therapy. Journal of Immunology and Vaccination. 2016;1:1-5.

7. Gerasun B.A., Holubovska 0.A., Hrytsko R.Y.,Zinchuk O.N. et al. Reduction of hyperproduction of thyroid autoantibodies in patients without disturbance of the thyroid function: New patents. Recent Patents on Endocrine, Metabolic \& Immune Drug Discovery. 2014; 8(2):140-145.

8. Herasun B.A., Hrytsko R.U. Original treatment methods of frequently recurrent chronic herpetic infection caused by herpes virus type I and type II. Central European Journal of Immunology. 2012; 37 (4):362-364.

9. Ho M., Armstrong J., McMahon D., Pazin G. et al. A phase 1 study of adoptive transfer of autologous CD8+ T lymphocytes in patients with acquired immunodefi ciency syndrome (AIDS)-related complex or AID: Blood. 1993; 81:2093-2101.

10. Chopyak V.V., Hospodarskyi I.Y., Gerasun B.A. Kyiv Clinical algorythm for rendering medical care to patients with polyclonal (mixed) cryoglobulinemic syndrome - D89,1 (Guidelines). Ministry of Health of Ukraine.2006; 33.

11. Herasun 0.B. Investigation of influence of intradermal immunization with noninactivated autoleukocytes on the condition of antiviral immunity in patients with chronic hepatitis B (Investigation in leukocyte culture). Gepatologia. 2016;32 (2): 24-30.

\section{ORCID and contributionship:}

Alexandr N. Zinchuk: 0000-0002-2768-3994 ${ }^{F}$

Borys A. Herasun: 0000-0001-7078-2659 A, D, E, F

Olga A. Golubovska: 0000-0003-3455-8718 ${ }^{F}$

Andrii M. Zadorozhnyi: 0000-0002-1116-2836 ${ }^{\mathrm{C}}$

Oleksandr B. Herasun: 0000-0003-2062-4630 B, D, E

\section{Conflict of interest:}

The Authors declare no conflict of interest.

\section{CORRESPONDING AUTHOR Andrii M.Zadorozhnyi \\ Danylo Halytsky National Medical University, 54 Pekarska St., 79010 Lviv, Ukraine tel:+380679920032; \\ e-mail:zadorozhnyi.andrij@gmail.com}

Received: 19.10 .2019

Accepted: 22.08 .2020

A - Work concept and design, B - Data collection and analysis, C - Responsibility for statistical analysis, D - Writing the article, $\mathbf{E}$-Critical review, $\mathbf{F}$ - Final approval of the article 